\title{
Causes of Reduced Pathogen Tolerance in Pelargonium after Application of Silver Thiosulfate
}

\author{
Christa Stark Whalen and George J. Wulster \\ Department of Horticulture, Rutgers University, New Brunswick, \\ NJ 08903
}

Additional index words. geranium, ethylene inhibitors, phenolic constituents, wound healing, aminooxyacetic acid, silver thiosulfate, sodium thiosulfate

\begin{abstract}
A silver thiosulfate (STS)-mediated increase in pathogen susceptibility was investigated using shoot cuttings from stock plants of pelargonium (Pelargonium hortorum Bailey cv. Ringo Scarlet) with and without STS treatment. Callusing and rooting were reduced in shoot cuttings from ST\&treated plants. The pathogen-tolerant tissue (no STS) was shown to produce enhanced levels of phenolic esters and glycosides during wound healing. Reactivity to the histochemical stain phloroglucinol-HCL was also enhanced during wound healing in cuttings from plants that had not received a silver treatment.
\end{abstract}

Plant mortality caused by Pythium ultimum rot was enhanced in pelargonium treated with silver to prevent flower petal abscission (Hausbek et al., 1984). Silver inhibits ethylene-mediated effects (Beyer, 1976; Glazer et al., 1984) and, presumably, also inhibits flower petal abscission by suppressing ethylene activity. Ethylene is a potential determinant of plant-pathogen interaction (Esquerré-Tugayk, 1984; Gaynor and Broglie, 1985; Stahman et al., 1966). The effects of silver thiosulfate (STS) on plant/pathogen interaction could thus be mediated by ethylene. Further, STS could have a positive effect on pathogen development and/or virulence. The effect might be dependent on the specific host/pathogen combination, or the host could simply be affected by STS treatment.

The objectives of this study were to investigate pathogen tolerance in pelargonium by determining the effects of STS on host metabolism. Most Pythium species, including $P$. ultimum, are nonspecific parasites that attack many economically important crops (Hendrix and Campbell, 1973). Thus, the results from the pelargonium study may be relevant to other crops.

Pelargonium stock plants were grown in soilless peat mix from seed (Harris Moran Seed Co., Rochester, N.Y.). The mix was prepared by supplementing sphagnum peat and horticultural grade vermiculite, $0.65 \mathrm{~m}^{3}$ each, with $6 \mathrm{~kg}$ limestone, $0.72 \mathrm{~kg} 0 \mathrm{~N}-$ $19.78 \mathrm{P}-\mathrm{OK}$ (triple superphosphate), $1.6 \mathrm{~kg}$ $5 \mathrm{~N}-4.3 \mathrm{P}-4.15 \mathrm{~K}, 0.05 \mathrm{~kg}$ fritted trace elements (FTE), $0.90 \mathrm{~kg}$ magnesium sulfate, and $0.96 \mathrm{~kg}$ AquaGrow wetting agent

Received for publication 21 May 1990. New Jersey Agricultural Experiment Station Publication no. D12152-15-90 supported by state and Hatch Act funds. The cost of publishing this paper was defrayed in part by the payment of page charges. Under postal regulations, this paper therefore must be hereby marked advertisement solely to indicate this fact.
(Aquatrols Corp. of America, Pennsauken, N.J.).

Rooting experiments. Shoot cuttings, 12 $\mathrm{cm}$ long and containing four fully expanded leaves per cutting, were taken from 5-monthold control stock plants or from similar plants that had received STS or sodium thiosulfate (TS) treatment $24 \mathrm{~h}$ before removal of the cuttings. The cuttings were propagated in perlite held at $21 \mathrm{C}$ under intermittent mist for 14 days. At the end of the propagation period, the roots were removed with a razor blade, dried at $45 \mathrm{C}$, and the root dry weight per cutting was recorded.

STS was prepared as described by Heins et al. (1984). A 1.0-mm solution of TS or STS was supplemented with Tween 20 $(0.01 \% \mathrm{v} / \mathrm{v})$ as a surfactant and applied to the stock plants as a foliar spray to runoff immediately after the solution had been prepared.

Aminooxyacetic acid (AOA) was applied to cuttings from nontreated 'Ringo Scarlet' plants in the form of a 6-h pulse of a 0.1mM solution of AOA ( $2.5 \mathrm{ml}$ uptake per cutting).

Histochemistry. Hand-cut fresh tissue sections were taken from shoot cuttings from nontreated and STS-treated stock plants. The tissue sections were taken from propagated cuttings at 24-h intervals 1 to 7 days after wounding. Longitudinal sections from 10 cuttings for each treatment were placed on

Table 1. Effects of aminooxyacetic acid (AOA), sodium thiosulfate (TS), and silver thiosulfate (STS) on adventitious root formation in 'Ringo Scarlet' Pelargonium shoot cuttings.

\begin{tabular}{lc}
\hline \hline Treatment & $\begin{array}{c}\text { Root dry wt/cutting } \\
\text { (mg) }\end{array}$ \\
\hline Control & $7.86 \mathrm{a}$ \\
AOA & $7.14 \mathrm{a}$ \\
TS & $7.87 \mathrm{a}$ \\
STS & $0.60 \mathrm{~b}$ \\
\hline
\end{tabular}

zMean separation by Ryan-Einot-Gabriel-Welsch multiple comparison test, $P=0.05$ (n $=60$ replicates). 
Table 2. Changes in phenolic constituents in shoot cuttings from nontreated and silver thiosulfate (STS)-treated 'Ringo Scarlet' Pelargonium plants during wound healing.

\begin{tabular}{|c|c|c|c|c|c|c|}
\hline \multirow[b]{3}{*}{ Day $^{z}$} & \multicolumn{6}{|c|}{ Phenolic constituents in gallic acid equivalents (mg) } \\
\hline & \multicolumn{2}{|c|}{ Free } & \multicolumn{2}{|c|}{ Ester-linked } & \multicolumn{2}{|c|}{ Glycoside-linked } \\
\hline & Control & STS & Control & STS & Control & STS \\
\hline 0 & 4.30 & 4.50 & 9.60 & 9.80 & 9.10 & 8.50 \\
\hline 4 & $4.20^{\mathrm{NS}}$ & $3.95^{\mathrm{NS}}$ & $11.10^{*}$ & $9.40^{\mathrm{NS}}$ & $10.20^{\mathrm{NS}}$ & $8.70^{\mathrm{NS}}$ \\
\hline 0 & 4.95 & 6.50 & 9.62 & 12.90 & 7.70 & 8.85 \\
\hline 6 & $3.40^{*}$ & $4.30^{*}$ & $11.60^{*}$ & $11.15^{*}$ & $8.05^{\mathrm{NS}}$ & $7.90^{*}$ \\
\hline
\end{tabular}

"Phenolic constituents were extracted the day of wounding $(0)$ and 4 and 6 days later.

$\mathrm{Ns}, *$ Nonsignificant or significant by two-tailed $t$ test, respectively, $P=0.05$ (n $=4$ replicates). Day 0 sample vs. day 4 or day 6 sample.

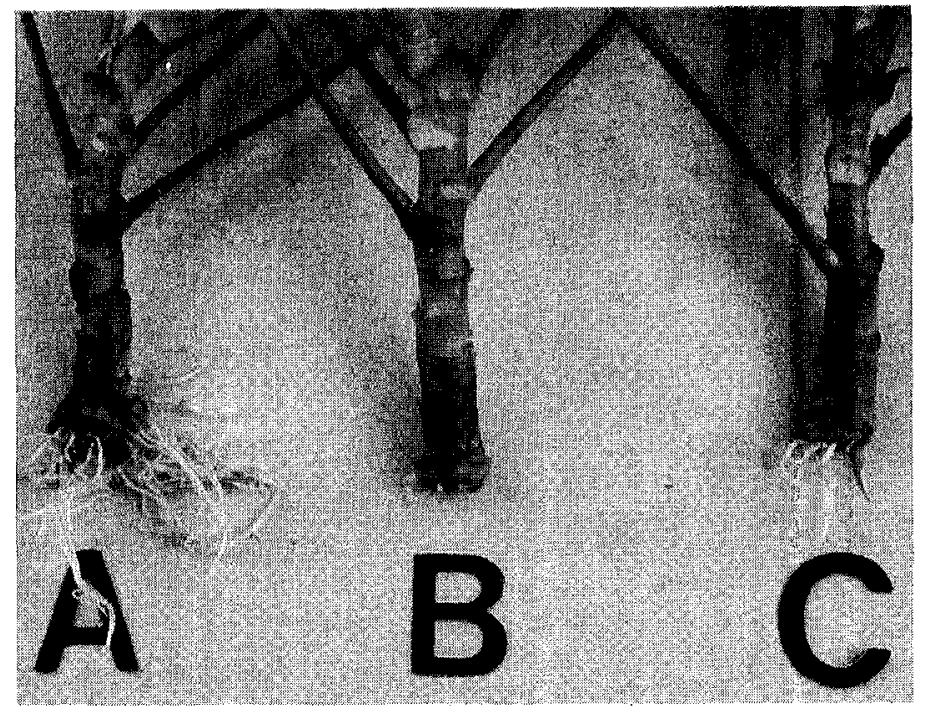

Fig. 1. Silver thiosulfate (STS) effects on rooting of 'Ringo Scarlet' Pelargonium shoot cuttings rooted for 14 days in perlite. $\mathrm{A}=$ Control; $\mathrm{B}, \mathrm{C}=$ cuttings from STS-treated plants.

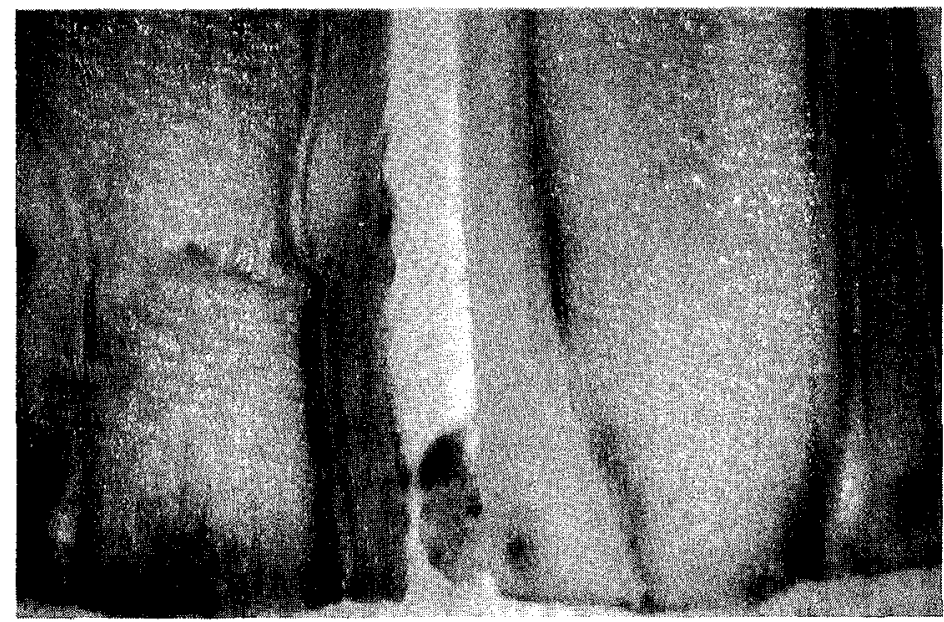

Fig. 2. Silver thiosulfate (STS) effects on synthesis of phloroglucinol-HCL-positive materials after wounding. (left) Control, (right) STS-treated.

glass slides and stained with a saturated solution of phloroglucinol in $25 \%(\mathrm{v} / \mathrm{v}) \mathrm{HCL}$ for 15 to $30 \mathrm{~min}$. The excess stain was removed with water after a suitable time for stain development. The sections were then mounted in glycerin and examined visually.

Phenolic accumulation. Phenolic constituents were measured in cuttings from thirty. nine 7-month-old stock plants each, nontreated or sprayed with STS 24 h before cutting removal. For each day and each treatment, tissue from 65 cuttings was taken and extracted. Phenolic constituents were extracted from $0.5-\mathrm{cm}$ stem sections taken proximal to the cut surface of pelargonium shoot cuttings that had been propagated in the greenhouse in perlite under intermittent mist. Stem base tissue was collected on the day of cutting and 4 and 6 days thereafter. Tissue was stored in plastic bags at $-75 \mathrm{C}$ until processed.

The frozen stem tissue was homogenized for $1 \mathrm{~min}$ in a Waring blender with $\approx 20 \mathrm{ml}$ of $80 \%$ methanol per gram of fresh tissue. The $80 \%$ methanol was prepared by diluting 99.9\% methanol certified American Chemical Society reagent with distilled water adjusted to $\mathrm{pH} 2$. The tissue was then extracted according to Dercks and Buchenauer (1986). The method was modified in that the antioxidant ascorbic acid was replaced by nitrogen gas, since ascorbic acid was determined to react positively with the Folin Denis reagent. Free, ester-linked, and glycosidic-linked pheholic constituents were determined.

Total phenolic constituents were assayed according to a procedure by Swain and Hillis (1959) and the Folin Denis reagent was prepared according to Hotwitz (1975).

The final extract from the $10 \mathrm{~g}$ and $5 \mathrm{~g}$ of tissue was diluted $1: 5$ or $1: 2(\mathrm{v} / \mathrm{v})$, respectively, with methanol (HPLC grade). Phenolic acid content was determined in 50- or $100-\mu \mathrm{l}$ aliquots of the diluted final extract and was within the linear range as determined by a gallic acid standard curve.

Absorbance was measured at $725 \mathrm{~nm}$ with a Shimadzu UV-VIS recording spectrophotometer, model P/N 204-04550 (Shimadzu Scientific Instruments, Columbia, Md.), in $1-\mathrm{cm}$ quartz cells using only water and reagent as a blank. Each extract was measured three times. The average value was calculated and reported as gallic acid equivalent. The gallic acid standard curve was linear between concentrations of 25 and $250 \mu \mathrm{g} / 25$ $\mathrm{ml}$ assay mixture.

Free, ester-linked, and glycosidic-linked phenolic constituent means were calculated from four extractions, each consisting of 5 or $10 \mathrm{~g}$ of plant tissue. Shoot cuttings for all experiments were arranged in a randomized block experimental design. Day 0 means were compared to day 4 or day 6 means using a two-tailed t test at $P=0.05$.

Silver treatment of 'Ringo Scarlet' stock plants $24 \mathrm{~h}$ before removal of the cuttings resulted in reduced callusing and rooting ability (Table 1, Fig. 1). From our experiments, it could not be determined whether rooting was inhibited or only delayed by STS. The reduced rooting ability was caused by STS and not TS (Table 1). Treating cuttings with the ethylene synthesis inhibitor AOA did not inhibit rooting (Table 1). Rooting inhibition caused by silver was, therefore, not likely the result of inhibition of ethylene action. This result is contrary to adventitious root formation in tomato, which was found to be induced by ethylene (Beyer, 1976).

Tissue from STS-treated 'Ringo Scarlet' plants observed 5 and 6 days after wounding had less phloroglucinol-HCL reactivity proximal to the cut surface than tissue from the control (Fig. 2). Phloroglucinol-HCL has been reported to stain both lignin and suberin (Cline and Neely, 1983; Craft and Audia, 1962). Lignin and suberin contain phenolics and are important in wound healing (Cline, 1980; Cline and Neely, 1983; Dean and Kolattukudy, 1977; Towers, 1964). Phenolic compounds were also reported to have a positive effect on rooting in pelargonium (Gad et al., 1987). 
The content of free phenolic constituents had not changed significantly in tissue from STS-treated and nontreated 'Ringo Scarlet' stock plants 4 days after the cuttings were taken, but 2 days later, the levels had decreased about equally in both (Table 2). Ester-linked phenolic levels were enhanced in nontreated 'Ringo Scarlet' tissue by 4 days after wounding and showed further increase at day 6 (Table 2). By contrast, the esterlinked phenolics had decreased slightly in tissue from STS-treated plants at 4 days after wounding and substantially by day 6 (Table 2). Glycosidic phenolic levels were essentially unchanged 4 or 6 days after wounding in nontreated plants (Table 2). However, in STS-treated tissue, glycoside levels were unchanged by 4 days after wounding, but had decreased significantly by 6 days (Table 2 ).

Consistent with observations of enhanced adventitious rooting of cuttings from control plants, we found more phloroglucinol-HCLpositive materials accumulated in tissue from nontreated plants than in tissue from STStreated plants. Also, differences in phenolic ester and glycoside accumulation occurred in tissue from control plants and STS-treated plants.

An STS effect on plant metabolism, independent of the pathogen but likely associated with pathogenesis, was demonstrated in this work.

\section{Literature Cited}

Beyer, E.M., Jr. 1976. Silver ion: A potent antiethylene agent in cucumber and tomato. HortScience 11(3):1.

Cline. M.N. 1980. The histology and histochemistry of the wound-healing process in geranium cuttings in relationship to basal stem rot caused by Pythium ultimum. PhD Diss., Univ. of Illinois, Urbana.

Cline, M.N. and D. Neely. 1983. The histology and histochemistry of the wound-healing process in geranium cuttings. J. Amer. Soc. Hort. Sci. 108(3)496-502.

Craft, C.C. and W.V. Audia. 1962. Phenolic substances associated with wound barrier formation of vegetables. Bot. Gaz. 123:211-219.

Dean, B.B. and P.E. Kolattukudy. 1977. Biochemistry of suberization: Incorporation of ${ }^{14} \mathrm{C}$ oleic acid and ${ }^{14} \mathrm{C}$-acetate into the aliphatic components of suberin in potato tuber discs (Solanum tuberosum). Plant Physiol. 59(1):48-54.

Dercks, W. and H. Buchenauer. 1986. Untersuchungen zum Einfluss von Aluminiumfosetyl auf den pflanzlichen Phenolstoffwechsel in den Pathogen-Wirt Beziehungen PhytophthorulFragaria -Erdbeere und Bremia/Lactuca -Salat. J. Phytopathol. 115:37-55.

Esquerré-Tugayé, M.T., D. Mazau, B. Pelissier, D. Roby. and A. Toppan. 1984. Elicitors and ethylene trigger defense responses in plants, $p$. 217-218. In: Y. Fuchs and E. Chalutz (eds.). Ethylene, biochemical, physiological and applied aspects. Martinus Nijoff/Junk, The Hague, Boston.

Gad, A.E., I. Ben-Efraim, M. Yavzury, H. Weinberg, and G. Friedman. 1987. Rooting and subsequent vegetative growth of geranium cuttings improved by 4-chloro-resorcinol. Israel J. Bot. 36:185-189.

Gaynor, J.J. and R. Broglie. 1985. Defense genes in bean seedlings: Induction of chitinase by ethylene, p. 617-627. In: M. Freeling (ed.). Plant genetics. Liss, Div. of John Wiley, New York. Glazer, I., A. Apelbaum, and D. Orion. 1984. Reversal of nematode-induced growth retardation in tomato plants by inhibition of ethylene action. J. Amer. Soc. Hort. Sci. 109(6):886889.

Hausbeck, M.K., C.T. Stephens, and R.D. Heins. 1984. STS/ Pythium interaction...does it exist? BP-News 15(4).

Heins, R.D., H:N. Fonda, and A. Cameron. 1984. Mixing and storage of silver thiosulphate. BPNews $15(7)$.

Hendrix, F.F., Jr., and W.A. Campbell. 1973. Pythium as plant pathogens. Annu. Rev. Phytopathol. 11:77-98.

Horwitz, W. (ed.). 1975. Folin Dennis reagent, p. 164-165. In: Official methods of analysis of the association of official analytical chemists. 12th ed. Assn. Official Analytical Chemists, Washington, D.C.

Stahman, M.A., B.G. Clare, and W. Woodbury. 1966. Increased disease resistance and enzyme activity induced by ethylene and ethylene production by black rot-infected sweet potato tissue. Plant Physiol. 41:1505-1512.

Swain. T. and Hillis. W.E. 1959. Phenolic constituents of Prunus domestica. J. Sci. Food Agr. 10:64-68.

Towers, G.H.N. 1964. Metabolism of phenolics in higher plants and microorganisms, p. 249294. In: J.B. Harborne (ed.). Biochemistry of phenolic compounds. Academic, New York. 